\title{
Partisipasi Pembudidaya Ikan dalam Kegiatan Penyuluhan Perikanan di Kecamatan Samarinda Utara Kota Samarinda
}

\author{
[Participation of the Fish Farmer in Fisheries Extension activities \\ at the District of North Samarinda, Samarinda] \\ Irma Yuliana ${ }^{\bowtie}$, Muhammad Syafril, Mohamad Ma'ruf \\ Fakultas Perikanan dan Ilmu Kelautan, Universitas Mulawarman \\ Jalan Kuaro, Gn. Kelua, Samarinda Ulu, Kota Samarinda, Kalimantan Timur 75119
}

Diterima : 10 Oktober 2017 ; Disetujui : 9 Desember 2017

\begin{abstract}
Abstrak
Tujuan dari penelitian ini adalah: 1) Mengukur jumlah pendapatan petani ikan. 2) Mengukur tingkat partisipasi petani ikan dalam kegiatan penyuluhan. 3) Menentukan hubungan antara faktor internal dan eksternal terhadap tingkat partisipasi, 4) Mengetahui faktor-faktor yang secara signifikan mempengaruhi tingkat partisipasi petani ikan. Pengambilan sampel menggunakan teknik proportional stratified random sampling. Data dianalisis dengan menggunakan empat metode yaitu analisis pendapatan, analisis tingkat partisipasi, analisis korelasi rank spearman dan regresi linier berganda. Hasil penelitian menunjukkan bahwa 1) pendapatan petani ikan sekitar Rp 86.142,86-Rp 7.030.753,97 /responden/bulan dengan rata-rata sebesar $\mathrm{Rp} 1.646 .550,60,2)$ tingkat partisipasi dalam kegiatan penyuluhan perikanan adalah tingkat sedang $(57,50 \%)$. 3) Hubungan antara faktor internal dan eksternal terhadap tingkat partisipasi dalam kegiatan penyuluhan perikanan adalah: a) faktor internal (pendapatan, jumlah tanggungan dan aktivitas kelompok) dan faktor eksternal (hubungan dengan konsultan perikanan, hubungan dengan pedagang, ketersediaan pasar informasi dan ketersediaan sains dan teknologi budidaya) memiliki korelasi yang signifikan dengan tingkat partisipasi dalam tahap perencanaan kegiatan penyuluhan, b) faktor internal (jumlah tanggungan dan aktivitas kelompok) dan faktor eksternal (hubungan dengan konselor perikanan, hubungan dengan pedagang, ketersediaan informasi pasar dan ketersediaan sains dan teknologi budidaya) memiliki korelasi yang signifikan tingkat partisipasi pada tahap implementasi, pemanfaatan fase manfaat dan tahap evaluasi. 4) Secara bersamaan, faktor internal dan eksternal berpengaruh signifikan terhadap tingkat partisipasi kegiatan penyuluhan perikanan, sementara hanya faktor eksternal yang mempengaruhinya.
\end{abstract}

Kata kunci: Partisipasi, petani ikan, penyuluhan perikanan

\begin{abstract}
The purposes of the research are : 1) Measuring the amount of fish farmer's income . 2) Measuring the participation level of fish farmer in extension activities. 3) Determine the relationship between internal and external factors on the participation level, 4) To know the factors that significantly affect the participation level of fish farmer. The sampling is using proportionate stratified random sampling technique. The data were analyzed using four methods which are income analysis, participation level analysis, Spearman rank correlation analysis and multiple linear regression. The results showed that 1) income of fish farmer is around IDR 86.142.86-IDR 7,030,753.97 / respondent / month with an average are IDR $1.646 .550,60,2)$ participation level in fisheries extension activities was the moderate levels (57.50\%). 3) The relationship between internal and external factors on the participation level in fisheries extension activities are: a) internal factors (income, number of dependents and group activities) and external factors (relationships with fisheries counselor, relationships with traders, the availability of market information and the availability of science and technology of cultivation) has a significant correlation to the participation level in the planning phase of extension activities, b) internal factors (number of dependents and group activities) and external factors (relationships with fisheries counselor, relationships with traders, the availability of market information and the availability of science and technology of cultivation) has a significant correlation the participation

\footnotetext{
$\triangle$ Penulis Korespondensi :

Alamat Surel : irmayuliana317@gmail.com
} 
level at the implementation phase, utilization of the benefit phase and evaluation phase. 4) Simultaneously, the internal and external factors significantly affected the participation level of fisheries extension activities, while partially only external factors that affected it.

Keywords: Participation, fish farmer, fisheries extension activities.

\section{PENDAHULUAN}

Kota Samarinda merupakan Ibu kota Provinsi Kalimantan Timur dan merupakan satu diantara kota terbesar di Provinsi Kalimantan Timur. Berdasarkan data Samarinda dalam Angka 2015, Kota Samarinda pada tahun 2014 memiliki jumlah penduduk 830.676 Jiwa dengan luas wilayah $71.800 \mathrm{Ha}$ (Samarinda dalam Angka, 2015). Jumlah penduduk yang besar tersebut akan memberikan dampak berupa tingginya tingkat kebutuhan konsumsi masyarakat yang berasal dari protein hewani, satu diantaranya bersumber dari komoditi ikan.

Kegiatan budidaya merupakan kegiatan perikanan yang mampu membantu masyarakat meningkatkan ekonomi melalui kegiatan perikanan, sehingga menjadi perhatian tersendiri bagi pemerintah Kota Samarinda dan Pemerintah Provinsi Kalimantan Timur untuk mengembangkan usaha ini. Kegiatan penyuluhan perikanan adalah satu diantara program pemberdayaan masyarakat untuk menunjang peningkatan kualitas hidup masyarakat pembudidaya ikan. Partisipasi masyarakat pembudidaya ikan merupakan modal utama dalam upaya mencapai sasaran program penyuluhan perikanan.
Berbagai upaya telah ditempuh oleh pemerintah Kecamatan Samarinda Utara untuk meningkatkan partisipasi masyarakat pembudidaya ikan dalam kegiatan penyuluhan perikanan seperti penguatan kelembagaan kelompok pembudidaya ikan dan pemberian bantuan kepada pembudidaya ikan seperti misalnya bantuan pemberian benih, induk dan fasilitas lainnya. Berdasarkan hal di atas, peneliti tertarik untuk meneliti Partisipasi Pembudidaya Ikan dalam Kegiatan Penyuluhan Perikanan di Kecamatan Samarinda Utara Kota Samarinda.

Adapun tujuan yang hendak dicapai dalam penelitian ini adalah untuk 1) mengukur besarnya pendapatan yang diperoleh pembudidaya ikan dari usaha budidaya ikan, 2) mengukur tingkat partisipasi pembudidaya ikan dalam kegiatan penyuluhan perikanan, 3) mengetahui hubungan antara faktor internal dan faktor eksternal terhadap tingkat partisipasi pembudidaya ikan dalam kegiatan penyuluhan perikanan dan 4) mengetahui faktor yang berpengaruh nyata terhadap tingkat partisipasi pembudidaya ikan dalam kegiatan penyuluhan perikanan di Kecamatan Samarinda Utara Kota Samarinda. 


\section{METODE PENELITIAN}

Penelitian dilakukan di Kecamatan Samarinda Utara Kota Samarinda dan dilaksanakan selama 8 bulan, yaitu mulai bulan September 2016 sampai dengan April 2017.

\section{Metode Pengumpulan Data}

Metode pengumpulan data yang diperlukan dalam penelitian ini menggunakan metode Survei. Data yang dikumpulkan mencakup data primer dan sekunder. Data primer diperoleh melalui wawancara dan pengamatan langsung di tempat penelitian. Sedangkan data sekunner adalah data yang diperoleh dari studi literatur dan lain-lainnya yang mendukung laporan ini serta berdasarkan dokumentasi yang diperoleh pada saat melakukan penelitian.

\section{Metode Pengambilan Sampel}

Populasi dalam penelitian ini adalah pelaksana kegiatan budidaya ikan yang tergabung dalam kelompok pembudidaya ikan di kecamatan Samarinda Utara. Adanya responden kunci (key informan) dalam penelitian ini diambil dengan teknik purposive sampling yaitu 1 Penyuluh PNS dan 1 Penyuluh Swadaya. Penentuan sampel pada tiap kelurahan dilakukan dengan teknik Proportionate Stratified Random Sampling, metode ini adalah teknik pengambilan sampel yang digunakan bilamana anggota stratum dalam populasi tidak sama (Zuriah, 2006).

\section{Metode Analisis Data}

Untuk mengukur besarnya pendapatan yang diperoleh pembudidaya ikan dari usaha budidaya ikan maka perlu melakukan analisis biaya, penerimaan dan pendapatan pembudidaya ikan (Rangkuti, 2012).

a. Analisis biaya

$$
T C=T F C+T V C
$$

Keterangan :

$\mathrm{TC}($ Total Cost $)=$ Total biaya $(\mathrm{Rp} /$ Tahun $)$.

TFC $($ Total Fixed Cost $)=$ Total biaya tetap (Rp/Tahun).

TVC $($ Total Variable Cost $)=$ Total biaya tidak tetap (Rp/Tahun).

b. Analisis Penerimaan

$$
T R=P \times Q
$$

Keterangan :

$\mathrm{TR}($ Total Revenue $)=$ Total penerimaan (Rp/Tahun)

$\mathrm{P}($ Price $)=$ Harga $(\mathrm{Rp} / \mathrm{kg})$

$\mathrm{Q}($ Quantity $)=$ Jumlah produksi $(\mathrm{kg})$

c. Analisis Pendapatan

$$
\pi=T R-T C
$$

Keterangan :

$\pi=$ Keuntungan bersih (Rp/Tahun)

$\mathrm{TR}$ (Total Revenue) $=$ Total penerimaan (Rp/Tahun)

$\mathrm{TC}($ Total Cost $)=$ Total biaya $(\mathrm{Rp} /$ Tahun $)$

Untuk mengetahui tingkat partisipasi pembudidaya ikan dalam kegiatan penyuluhan perikanan (Y) dan tanggapan pembudidaya ikan terhadap peran penyuluh, maka digunakan perhitungan :

$\frac{\text { Jumlah skor jawaban responden }}{\text { jumlah skor tertinggi }} \times 100 \%$ 
Kriteria interpretasi data untuk tanggapan pembudidaya terhadap peran penyuluh perikanan :

Angka 33,33 \% - 55,55\%= Kurang

Angka 55,56 \% - 77,77 \% = Cukup

Angka $77,78 \%-100 \%=$ Baik

Selanjutnya hubungan antar sub variabel diketahui dengan menggunakan uji korelasi Rank Spearman. Untuk melihat pengaruh variabel $\mathrm{X}_{1}$ (faktor internal) dan $\mathrm{X}_{2}$ (faktor eksternal) terhadap variabel Y (tingkat partisipasi pembudidaya ikan dalam kegiatan penyuluhan perikanan) secara simultan maupun parsial menggunakan analisis regresi linear berganda dengan model (Gujarati, 1997) :

$$
Y=a+b_{1} X_{1}+b_{2} X_{2}+e
$$

Keterangan :

$\mathrm{Y}=$ Tingkat Partisipasi Pembudidaya Ikan dalam Kegiatan Penyuluhan Perikanan

$\mathrm{X}_{1}=$ Faktor Internal

$\mathrm{X}_{2}=$ Faktor Eksternal

$b_{1}$ dan $b_{2}=$ Koefisien variabel bebas $X_{1}$ dan $X_{2}$

$\mathrm{e}=$ Gallat (error)

\section{HASIL DAN PEMBAHASAN}

\section{A. Kinerja Ekonomi}

Tabel 1. Tingkat Partisipasi Pembudidaya Ikan dalam Kegiatan Penyuluhan Perikanan

\begin{tabular}{llcc}
\hline Kegiatan Penyuluhan Perikanan & Tingkat Partisipasi (\%) & Keterangan \\
\hline 1. & Perencanaan & 45,21 & Rendah \\
2. & Pelaksanaan & 66,67 & Sedang \\
3. & Pemanfaatan Hasil & 60,21 & Sedang \\
4. & Evaluasi/Penilaian & 57,92 & Sedang \\
\hline \multicolumn{2}{c}{ Rata-rata } & 57,50 & Sedang \\
\hline
\end{tabular}


Biaya tidak tetap merupakan biaya yang berhubungan dengan proses produksi secara keseluruhan. Jumlah biaya tidak tetap untuk 40 orang pembudidaya ikan berada pada interval Rp. 1.920.000,00/ tahun/ responden sampai dengan $\mathrm{Rp}$. 120.984.000,00/ tahun/ responden dengan rata-rata Rp. 23.621.850,00/ tahun/ responden atau Rp. 1.968.487,00/ bulan/ reponden.

\section{Penerimaan dan Pendapatan}

Jumlah penerimaan dari 40 orang pembudidaya ikan berada pada interval $\mathrm{Rp}$ 10.800.000/tahun/responden sampai deng-

\section{B. Tingkat Partisipasi}

Partisipasi pembudidaya ikan tergolong kategori sedang cenderung rendah dikarenakan pembudidaya ikan kurang

Tabel 2. Hubungan antara Sub Variabel $\mathrm{X}_{1}$ terhadap Sub Variabel Y.

\begin{tabular}{llrrrr}
\hline No. & \multicolumn{1}{c}{ Sub Variabel } & $\begin{array}{c}\text { Perencanaan } \\
\left(\mathbf{Y}_{\mathbf{1}}\right)\end{array}$ & $\begin{array}{c}\text { Pelaksanaan } \\
\left(\mathbf{Y}_{2}\right)\end{array}$ & $\begin{array}{c}\text { Pemanfaatan } \\
\text { Hasil }\left(\mathbf{Y}_{3}\right)\end{array}$ & Evaluasi $\left(\mathbf{Y}_{4}\right)$ \\
\hline 1. & Umur $\left(\mathrm{X}_{1.1}\right)$ & 0,271 & 0,039 & $-0,155$ & 0,026 \\
2. & Pendidikan $\left(\mathrm{X}_{1.2}\right)$ & $-0,147$ & $-0,191$ & 0,002 & 0,031 \\
3. & Pengalaman Budidaya $\left(\mathrm{X}_{1.3}\right)$ & $-0,106$ & $-0,295$ & $-0,269$ & $-0,210$ \\
4. & Pendapatan $\left(\mathrm{X}_{1.4}\right)$ & $0,402^{*}$ & 0,236 & 0,297 & 0,268 \\
5. & Luas Lahan $\left(\mathrm{X}_{1.5}\right)$ & 0,186 & 0,265 & 0,291 & 0,272 \\
6. & Tanggungan $\left(\mathrm{X}_{1.6}\right)$ & $0,580^{* *}$ & $0,436^{* *}$ & $0,476^{* *}$ & $0,586^{* *}$ \\
7. & Kegiatan Kelompok $\left(\mathrm{X}_{1.7}\right)$ & $0,350^{*}$ & $0,404^{* *}$ & $0,578^{* *}$ & $0,569^{* *}$ \\
\hline
\end{tabular}

Sumber : Data Primer yang diolah, 2017.

Keterangan :

$\mathrm{r}_{\mathrm{s}}(\mathrm{db}=40)$ dengan $\alpha 0,05=0,313$

$\mathrm{r}_{\mathrm{s}}(\mathrm{db}=40)$ dengan $\alpha 0,01=0,405$ 
a. Pembudidaya ikan belum mendapatkan bukti konkret (nyata) mengenai keuntungan yang diperoleh jika terlibat lebih dalam kegiatan penyuluhan.

b. Selama ini materi penyuluhan yang diperoleh oleh pembudidaya ikan

e. Kegiatan penyuluhan saat ini masih berkaitan dengan kemampuan memenuhi atau memberikan jalan untuk mendapatkan modal usaha (berupa barang maupun modal pinjaman/hibah).

A. Hubungan Faktor Internal dan Faktor Eksternal terhadap Tingkat Partisipasi Pembudidaya Ikan dalam Kegiatan Penyuluhan Perikanan

Hipotesis penelitian yang menyatakan bahwa faktor internal yaitu Jumlah tanggungan dan kegiatan kelompok berhubungan secara nyata (signifikan) dengan tingkat partisipasi pembudidaya ikan dalam kegiatan penyuluhan perikanan diterima kebenarannya, sedangkan pada pendapatan hanya memiliki hubungan yang signifikan terhadap tahapan perencanaan kegiatan penyuluhan perikanan. Hal ini dibuktikan dengan nilai $r_{s}$ hitung lebih dari $r_{s}$ tabel $(\alpha=0,05)$.

Pembudidaya ikan dengan pendapatan tinggi akan cenderung tinggi juga partisipasinya pada tahap per-encanaan, namun pada saat pelaksanaan penyuluhan berupa transfer iptek, par-tisipasinya belum memenuhi kebutuhan dan keinginan dari pembudidaya ikan.

c. Kegiatan penyuluhan perikanan kadang-kadang masih sebatas

d. Kegiatan inventalisir (mendata) kondisi usaha dari pembudidaya ikan.

menurun. Jumlah tanggung-an keluarga berpengaruh terhadap jumlah kebutuhan hidup yang harus dipenuhi oleh pembudidaya ikan sebagai kepala rumah tangga. Pembudidaya ikan akan melakukan usaha yang dapat memenuhi kebutuhan rumah tangga tersebut. Peningkatan produktivitas usaha budidaya menjadi pilihan tambahan dalam meningkatkan ekonomi keluarga. Pem-budidaya akan meningkatkan partisipasi-nya pada kegiatan penyuluhan perikanan yang dianggap memberikan dampak positif terhadap usaha budidaya ikan tersebut.

Semakin aktif pembudidaya dalam kegiatan kelompok pembudidaya ikan maka akan semakin tinggi pula tingkat partisipasinya dalam kegiatan penyuluhan perikanan. Hal ini dikarenakan keaktifan pembudidaya ikan dalam kegiatan kelompok akan mempermudah pembudi-daya tersebut untuk mendapat informasi mengenai kegiatan penyuluhan yang mampu meningkatkan kinerja usahanya.

Hipotesis penelitian yang men-nyatakan bahwa faktor eksternal ber- 
hubungan secara nyata dengan tingkat partisipasi pembudidaya ikan dalam kegiatan penyuluhan perikanan diterima kebenarannya. Hal ini dibuktikan dengan nilai $r_{s}$ hitung lebih dari $r_{s}$ tabel $(\alpha=0,05)$.

Penyuluh perikanan secara tidak langsung akan melibatkan anggota kelompok pembudidaya ikan yang memiliki kedekatan dengan penyuluh

diperoleh jika mampu memenuhi kebutuhan pasar dalam hal penyediaan (supply) komoditi ikan air tawar.

Tersedianya informasi pasar yang berkaitan dengan tingkat permintaan berbagai komoditi ikan sesuai dengan harga pasar akan mempermudah pembudidaya ikan dalam memilih komoditi bernilai ekonomis tinggi untuk dibudidayakan, sehingga pembudidaya ikan akan meningkatkan partisipasinya dalam kegiatan penyuluhan perikanan dalam rangka menghasilkan produksi yang optimal. Hal ini disebabkan Pembudidaya. perikanan, pada 4 tahap kegiatan penyuluhan tersebut. Semakin dekat pembudidaya ikan dengan pedagang/pengumpul maka pengetahuan pembudidaya mengenai informasi pasar akan cukup luas dan aktual berkenaan dengan manfaat (benefit) ekonomi yang

ikan merasa adanya manfaat dari kegiatan penyuluhan perikanan berupa bantuan fisik dan nonfisik yang dapat menunjang hasil produksi.

Ketersediaan iptek tinggi maka akan diikuti oleh tingginya tingkat partisipasi pembudidaya ikan dalam kegiatan penyuluhan perikanan. Hal ini memberikan penafsiran bahwa ketersediaan iptek yang cukup tinggi tentunya meningkatkan motivasi mereka untuk menerapkan iptek tersebut pada usaha budidaya ikan

Tabel 3. Hubungan antara Sub Variabel $\mathrm{X}_{2}$ terhadap Sub Variabel Y.

No. Sub Variabel

\begin{tabular}{lccccc}
\hline 1. & Interaksi dengan Penyuluh $\left(\mathrm{X}_{2.1}\right)$ & $0,653 * *$ & $0,806 * *$ & $0,889 * *$ & $0,697 * *$ \\
2. & Interaksi dengan Pedagang $\left(\mathrm{X}_{2.2}\right)$ & $0,623^{* *}$ & $0,510^{* *}$ & $0,453 * *$ & $0,399 *$ \\
3. & Ketersediaan Informasi Pasar $\left(\mathrm{X}_{2.3}\right)$ & $0,399 *$ & $0,519 * *$ & $0,571 * *$ & $0,448 * *$ \\
4. & Ketersediaan IPTEK Budidaya $\left(\mathrm{X}_{2.4}\right)$ & $0,436 * *$ & $0,557 * *$ & $0,607 * *$ & $0,389 *$
\end{tabular}

$\mathrm{r}_{\mathrm{s}}(\mathrm{db}=40)$ dengan $\alpha 0,05=0,313$

$\mathrm{r}_{\mathrm{s}}(\mathrm{db}=40)$ dengan $\alpha 0,01=0,405$ 
Penerapan iptek pada kegiatan budidaya ikan tidak terlepas dari peran penyuluh dalam mengarahkan dan membimbing pembudidaya ikan dalam kegiatan penyuluhan tersebut dan sarana produksi yang dibutuhkan pembudidaya guna

\section{B. Analisis Pengaruh Faktor Internal} $\left(X_{1}\right)$ dan Faktor Eksternal $\left(X_{2}\right)$ Terhadap Tingkat Partisipasi Pembudidaya Ikan dalam Kegiatan Penyuluhan Perikanan $(Y)$.

Berdasarkan Tabel 4 diatas, maka diperoleh persamaan regresi sebagai berikut, dengan t hitung ditunjukkan dalam kurung :

$\mathrm{Y}=-14,775+0,706 \mathrm{X}_{1}+0,897 \mathrm{X}_{2}$

$$
(-3,194) \quad(1,897) \quad(7,375)
$$

Pengujian hipotesis yaitu Fhitung $(47,084)$ lebih besar dari $F_{\text {tabel }}(2,60)$, sehingga Ha diterima dan Ho ditolak. Hal

penerapan iptek. Sarana produksi tersebut sepenuhnya belum mampu diadakan sendiri oleh pembudidaya sehingga harus mendapat bantuan dari pihak lain yang difasilitasi dan dimediasi oleh penyuluh.

ini menunjukkan bahwa faktor-faktor tersebut yaitu faktor internal $\left(\mathrm{X}_{1}\right)$ dan faktor eksternal $\left(\mathrm{X}_{2}\right)$ secara bersama-sama (simultan) mempunyai pengaruh nyata terhadap tingkat partisipasi pembudidaya ikan dalam kegiatan penyuluhan perikanan (Y) dapat diterima kebenarannya.

C. Hasil Analisis Regresi Pengaruh Variabel Bebas $\left(X_{1}\right.$ dan $\left.X_{2}\right)$ Terhadap Variabel Terikat (Y) secara Parsial. Analisis ini digunakan untuk melihat pengaruh masing-masing $\mathrm{x}$ (Variabel bebas) terhadap Y (Variabel terikat pada taraf kepercayaan $95 \%$

Tabel 4. Hasil analisis regresi antara variabel $\left(\mathrm{X}_{1}\right)$ dan $\left(\mathrm{X}_{2}\right)$ terhadap variabel $(\mathrm{Y})$.

\begin{tabular}{|c|c|c|c|c|c|c|}
\hline Variabel & B & SE & $\mathrm{T}$ & Sig.t & $\begin{array}{c}\text { Partial } \\
\text { Corelations }\end{array}$ & VIF \\
\hline Constant & $-14,775$ & 4,626 & $-3,194$ & 0,003 & & \\
\hline $\mathrm{X}_{1}$ & 0,706 & 0,372 & 1,897 & 0,066 & 0,298 & 1,314 \\
\hline $\mathrm{X}_{2}$ & 0,897 & 0,122 & 7,375 & 0,000 & 0,771 & 1,314 \\
\hline Keterangan & $:$ & $\mathrm{F}_{\text {Hitung }}$ & $: 47,084$ & & & \\
\hline Multiple R & $: 0,847$ & Signif.F hit & $: 0,000$ & & $\mathrm{t}_{0,05(38)}$ & $=1,960$ \\
\hline $\mathrm{R}_{\text {Square }}$ & $: 0,718$ & $\bar{R}^{2}$ & $: 0,703$ & & $\mathrm{~F}_{0,05(3,37)}$ & $=2,60$ \\
\hline
\end{tabular}

Sumber : Disarikan dari Lampiran 6. 
$(\alpha=0,05)$. Faktor internal $\left(X_{1}\right)$ yang meliputi 7 sub variabel secara bersamasama tidak mampu mempengaruhi tingkat partisipasi anggota kelompok pembudidaya ikan. Nilai indikator sub variabel faktor internal yang berada pada posisi baik atau tinggi akan mempengaruhi tingkat partisipasi pembudidaya ikan dalam kegiatan penyuluhan perikanan. Secara keseluruhan nilai indikator faktor internal berada pada tingkatan yang sedang cenderung rendah sehingga tidak berpengaruh terhadap tingkat partisipasi pembudidaya ikan.

Faktor eksternal $\left(\mathrm{X}_{2}\right)$ yang meliputi 4 sub variabel secara bersama-sama mampu mempengaruhi tingkat partisipasi anggota kelompok pembudidaya ikan. Semakin tinggi kemampuan pembudidaya dalam memenuhi kriteria dari sub variabel faktor eksternal tersebut maka semakin tinggi tingkat patisipasi mereka untuk dapat melibatkan diri dalam 4 tahapan kegiatan penyuluhan. Secara keseluruhan nilai indikator faktor eksternal berada pada tingkatan yang sedang cenderung tinggi untuk mempengaruhi tingkat partisipasi.

\section{Uji kebaikan model (goodnes of fit)}

Nilai koefisien korelasi terkoreksi $\left(\mathrm{R}^{2}\right.$ adjusted) sebesar 0,703. Nilai koefisien ini memberikan penafsiran bahwa kemampuan variabel-variabel bebas yang terdiri dari faktor internal $\left(\mathrm{X}_{1}\right)$ dan faktor eksternal $\left(\mathrm{X}_{2}\right)$ memiliki kemampuan dalam menjelaskan keragaman atau fluktuasi dari variabel Y (tingkat partisipasi pembudidaya ikan dalam kegiatan penyuluhan) sebesar $70,3 \%$, sisanya yaitu $29,7 \%$ dijelaskan oleh variabel-variabel lain yang tidak dima-sukkan di dalam model tetapi diwakili oleh nilai error atau galat (ei).

\section{KESIMPULAN DAN SARAN}

\section{Kesimpulan}

1. Pendapatan yang diperoleh pembudidaya ikan berkisar Rp 86.142,86/ responden /bulan Rp 7.030.753,97/ responden/ bulan dengan rata-rata $\mathrm{Rp}$ 1.646.550,60/ responden / bulan.

2. Tingkat partisipasi pembudidaya ikan dalam kegiatan penyuluhan perikanan berada pada tingkat sedang $(57,50 \%)$.

3. Hubungan antara faktor internal dan faktor eksternal terhadap tingkat partisipasi pembudidaya ikan adalah sebagai berikut :

a. Faktor internal (pendapatan, jumlah tanggungan dan kegiatan kelompok) dan faktor eksternal (hubungan dengan penyuluh perikanan, hubungan dengan pedagang, tersedianya informasi pasar dan tersedianya iptek budidaya) memiliki korelasi yang nyata terhadap 
tingkat partisipasi pembu-didaya ikan pada pada tahapan perencanaan kegiatan penyuluhan perikanan.

b. Faktor internal (jumlah tanggungan dan kegiatan kelompok) dan faktor eksternal (hubungan dengan penyuluh perikanan, hubungan dengan pedagang, tersedianya informasi pasar dan tersedianya iptek budidaya) memiliki korelasi yang nyata terhadap tingkat partisipasi pembudidaya ikan pada pada tahapan pelaksanaan, pemanfaatan hasil dan evaluasi kegiatan penyuluhan perikanan.

4. Secara simultan faktor internal dan faktor eksternal berpengaruh nyata terhadap tingkat partisipasi pembudidaya ikan dalam kegiatan penyuluhan perikanan, sedangkan secara parsial hanya faktor eksternal yang berpengaruh nyata terhadap tingkat partisipasi pembudidaya ikan dalam kegiatan penyuluhan perikanan.

\section{Saran}

1. Perlu adanya penelitian lebih lanjut mengenai peranan penyuluh perikanan dalam penguatan kelompok pembudidaya ikan dan peningkatan kinerja usaha budidaya ikan dalam kolam yang dilakukan oleh kelompok pembudidaya ikan di Kecamatan Samarinda Utara.
2. Perlunya peningkatan kapasitas (kuantitas dan kualitas) penyuluh perikanan yang dapat melakukan pembinaan terhadap usaha budidaya ikan oleh kelompok pembudidaya ikan yang mencakup 4 tahapan penyuluhan perikanan tersebut.

\section{DAFTAR PUSTAKA}

Gujarati, D. 1997. Ekonometrika Dasar. Terjemahan AK. Sumarno Zain. Erlangga, Jakarta

Kecamatan Samarinda Utara. 2015. Monografi Kecamatan Samarinda Utara. Samarinda. 27 hal.

Rangkuti, F. 2012. Studi Kelayakan Bisnis dan Investasi. Jakarta: Gramedia Pustaka Utama

Zuriah, N. 2006. Metodologi Penelitian Sosial dan Pendidikan TeoriAplikasi. Jakarta: Bumi Aksara. 291 Hal. 